\title{
Screening of indigenous rhizobacteria
} as potential biological control against faba bean (Vicia faba L.) gall disease caused by Olpidium viciae

\author{
Alemayehu Dugassa $^{1^{*}} \mathbb{0}$, Tesfaye Alemu ${ }^{1}$ and Yitbarek Woldehawariat ${ }^{2}$
}

\begin{abstract}
Background: Emerged faba bean gall disease attacks the stem and leaves of the plant and results in complete crop losses. This study was initiated to screen multi-trait rhizobacteria for their antagonistic efficacy under in-vitro and in-vivo conditions against Olpidium viciae to control the effect of gall disease on faba bean. Sixty antagonistic isolates were first examined for their morphological, biochemical, and phenotypic traits.

Results: Pseudomonas fluorescens AAUPF62, P. aeruginosa AAUS31, Bacillus AAUMF42, and Bacillus AAUAm28 showed greater than 68,62, 57, and 54\% suppression of O. viciae in dual culture, volatile metabolites, culture filtrate assay, and detached leaves experiments, respectively. The in-vivo study revealed that early treatment of the crop with $P$. aeruginosa AAUS31 reduced severity by 63\% (in FB-Obse) and 54\% (in FB-26869) faba bean varieties. The co-inoculation of $P$. fluorescens AAUPF62 and P. aeruginosa AAUS31 significantly enhanced the shoot $(P=0.003$; mean $=122 \mathrm{~cm})$ and root $\left(P=0.018\right.$; mean $=94 \mathrm{~cm}$ ) length, increased shoot dry weight by 8 factors $\left(83 \mathrm{~g} \mathrm{pot}^{-1}\right)$, and reduced final disease severity by $92 \%$ in FB-Obse variety.

Conclusions: The results revealed that P. fluorescens AAUPF62 and P. aeruginosa AAUS31 strains could be the potential antagonistic agents of gall disease. The use and early treatment of moderately resistant faba bean varieties by co-inoculation of synergistic potential bioagents were recommended.
\end{abstract}

Keywords: Biocontrol, Co-inoculation, Gall disease, In-vivo, Rhizobacteria, Vicia faba

\section{Background}

Faba bean (Vicia faba L.) is a grain legume crop widely cultivated in the highlands of Ethiopia as the main source of protein for human nutrition (Asfaw et al. 2018). In recent years the newly emerged faba bean gall disease caused by plant debris and soil-borne fungal pathogen (Olpidium viciae Kusano) becomes one of the major faba bean production constraints in faba bean growing areas

\footnotetext{
*Correspondence: alemayehudugassa2008@gmail.com

1 Department of Microbial, Cellular and Molecular Biology, College of Natural and Computational Sciences, Addis Ababa University, 1176 Addis Ababa, Ethiopia

Full list of author information is available at the end of the article
}

at an altitude greater than $2400 \mathrm{~m}$ above sea level (Bogale et al. 2017). To curb this problem, various management strategies have been carried out which depend mainly on an application of chemical fungicides since its occurrence (Teferi et al. 2018). However, the use of a chemical fungicide is not ecofriendly and could result in the emergence of fungicide resistance plant pathogens (Singh et al. 2013). Despite various management efforts made by researchers, the distribution pattern of faba bean gall disease was continued at escalating speed.

Hence, searching for supplementary indigenous biological control methods is a promising option. Biological control is a potential non-chemical means for plant 
disease management that reduces the harmful effects of the pathogen through the use of other living entities (Ferreira et al. 2020). The application of biological controls using antagonistic micro-organism is ecofriendly (Zhou et al. 2016) and has proved to be successful in controlling various plant diseases in many countries (Khaledi and Taheri 2016). More recently a good result has been obtained with beneficial bacteria that are indigenous to the rhizosphere of plants. The rhizosphere supports a metabolically active group of bacteria known as plant growth-promoting rhizobacteria (Alsohim et al. 2014). Rhizobacteria are plant-associated bacteria, derived from many genera that can colonize roots and suppresses the growth of soil-borne phytopathogens through various mechanisms (Dinesh et al. 2015). Pseudomonas and Bacillus species are among the rhizobacteria that can act against phytopathogens in plant root vicinity (Mota et al. 2017).

Pseudomonas spp. are common Gram-negative, nonspore-forming, rod-shaped bacteria (Gómez-Lama et al. 2018) whereas Bacillus spp. are Gram-positive sporeforming, rod-shaped bacteria (Suthar et al. 2017). Due to their various genetic and phenotypic characteristics, members of these genera have good potential to be used as biocontrol agents (Zhou et al. 2016). Rhizobacteria employed either direct or indirect disease control mechanisms which include plant growth promotion, production of hydrolytic enzymes, siderophore, hydrogen cyanide $(\mathrm{HCN})$, and competition with disease-causing microbes for niches and nutrients (Audrain et al. 2015). Finally, they developed induction of systematic resistance in the plants (Haddoud et al. 2017).

Rhizobacteria are extensively used in the control of several diseases of crop plants (Abjala et al. 2015). However, there is limited knowledge regarding the biological suppression of Olpidium viciae Kusano in faba bean by application of rhizobacteria in Ethiopia. This study aimed to isolate bacteria from faba bean rhizosphere and screen the organism for in-vitro and in-vivo antagonistic activity against faba bean gall disease causal agent. Hence, this may contribute to the application of rhizobacteria as a biological control of the test pathogen in faba bean and other leguminous plants in Ethiopia.

\section{Methods}

\section{Collection of the test pathogen}

Previously isolated Olpidium isolate 4 (AAUO4) was obtained from the stock cultures originally isolated from naturally infected faba bean leaves samples with gall disease symptoms, collected from different localities of Angolelana Tera and Sululta districts, North Shoa, Ethiopia. The Potato Dextrose Agar (PDA) medium supplemented with chloramphenicol was used for reactivation, multiplication, and preservation of AAUO4 strain for further use.

\section{Rhizobacterial antagonists Isolation of rhizobacteria antagonists}

A total of 150 health faba bean plant rhizosphere soil samples were randomly collected from Angolelana Tera (50 samples), Sululta (50 samples), and Medakegn (50 samples) districts at $20 \mathrm{~cm}$ depth. Using standard serial dilution techniques (Islam et al. 2018), $0.1 \mathrm{ml}$ of each soil sample was pipetted into autoclaved nutrient agar medium. A total of 120 different bacterial colonies were sub-cultured and purified on the appropriate medium. The pure isolates were kept at $4{ }^{\circ} \mathrm{C}$ on nutrient agar slant for the next use.

\section{Characterization and evaluation of the bacterial isolates for biological control traits}

In the preliminary stage, in-vitro dual culture techniques were used to identify the potential antagonistic rhizobacteria strains against the test pathogen on potato dextrose agar medium. Then, 60 stains were selected, characterized, and identified based upon their morphological, phenotypic, and biochemical characteristics (Suthar et al. 2017).

The biochemical characteristics of isolates were assayed aimed to evaluate lipopolysaccharide (Mota et al. 2017), catalase (Dinesh et al. 2015), oxidase (Suthar et al. 2017) activities, and citrate utilization of the stains (Abjala et al. 2015). Phenotypes associated with biological control activities like hydrolytic enzymes amylase (Mota et al. 2017), protease (Audrain et al. 2015), cellulase (GómezLama et al. 2018), and chitinase (Abjala et al. 2015) production capacity of the strains were examined to identify the potential antagonistic rhizobacterial isolates. Likewise, the plant growth promotion traits of the strains were evaluated for siderophore (Gómez-Lama et al. 2018), Hydrogen Cyanide (HCN) (Nandini et al. 2017), Indole-3-Acetic Acid (IAA) production (Dinesh et al. 2015), and phosphate solubilization (Suthar et al. 2017). The phosphate solubilization efficiency (SE) of the isolates was calculated and determined using the following formula (Suthar et al. 2017).

$$
\mathrm{SE}=\frac{(\text { diameter of solubilization halo zone }) \times 100}{\text { Diameter of colony }+ \text { halo zone }}
$$

Physico-chemical stress tolerance of rhizobacterial strains Stress tolerance of selected strains was assessed on nutrient agar medium by determining their ability to grow at different $\mathrm{pH}$ values (Mota et al. 2017), temperature and salt ( $\mathrm{NaCl})$ concentrations (Kaur et al. 2018). Similarly, 
fungicides (Mancozeb 80\% WP and Copper Oxy Chloride $50 \% \mathrm{WP}$ ), and bactericides (Copper Hydroxide $53.8 \% \mathrm{WP}$ ) intrinsic resistance of the strains were evaluated at 50,100,200,300, and $400 \mathrm{ppm}$ of commercial formulations on nutrient agar medium followed by the food poison technique (Mishra et al. 2013). The medium without the test chemicals served as control. Spot inoculated plates with each bacterial isolate (loop full, $10^{6}$ cells $\mathrm{mL}^{-1}$ ) were incubated at $28 \pm 2{ }^{\circ} \mathrm{C}$ for five days. Three replications were maintained for each experiment and the growth of the bacterial isolates were qualitatively evaluated as (-) for no growth and as (+) for the presence of growth.

\section{In-vitro antagonism assay of rhizobacterial strains against Olpidium viciae}

To determine the in-vitro antagonism activity of bacterial strains, dual cultures were performed in PDA media plates as described by Islam et al. (2018). Production of volatile metabolites having antagonistic activity against fungal pathogens was tested by the paired plate technique (Cernava et al. 2015). In an antagonistic assay of bacterial culture filtrates, the culture was centrifuged at $10,000 \mathrm{rpm}$ for $30 \mathrm{~min}$ to get the cell-free filtrate (Mota et al. 2017). The culture filtrate was tested for its efficacy against fungal pathogens at 15,25 , and $40 \%$ concentrations. The tested pathogen was inoculated at the center of the plates both in the antagonistic assay of volatile antifungal metabolites and culture filtrates. Control was maintained and incubated for 14 days at $23 \pm 2{ }^{\circ} \mathrm{C}$. Three replications were maintained for each treatment. After the period of incubation, the percentage of inhibition of the test pathogen was calculated followed the following formula (Islam et al. 2018).

$$
\% \text { inhibition }=\frac{(R 1-R 2) \times 100}{R 1}
$$

where $R 1$-mycelial growth in control, $R 2$-mycelial growth in dual culture.

\section{Detached leaves experiments}

In-vitro detached leaf dual culture antagonistic assay of rhizobacterial strains against $O$. viciae was conducted on susceptible health faba bean (FB-26869) leaf let's according to Ali et al. (2020) in two independent experiments. The cell suspensions $\left(10^{8} \mathrm{CFU} \mathrm{mL}^{-1}\right)$ of each bacterial strain were prepared by standardized techniques according to Mota et al. (2017). Each surface-sterilized detached leaflet was soaked in bacterial cell suspensions and placed face-up on the filter paper impregnated with sterile distilled water in the sterilized Petri plates to serve as a moist chamber. Three leaflets were placed per plate.
Experiment $1 \mathrm{~A} 4 \mathrm{~mm}$ agar plugs of 14 days old pure test pathogen was placed at the center leaflets by using a sterile scalpel.

Experiment 2 Faba bean stems with gall disease symptoms were collected and $4 \mathrm{~mm}$ discs of the infected portion were surface sterilized and placed at the center of leaflets.

In both experiments, the leaflets only inoculated with the pathogen served as a positive control. Whereas, leaflets without bacterial cell suspension and the fungal pathogens were served as the negative control. Three replicates were maintained for each experiment. They were kept in an incubator for 6 days at room temperature $\left(20 \pm 3{ }^{\circ} \mathrm{C}\right)$. The length and width diameters of the leaf lesions formed around each agar plug and infected faba bean stem discs were measured. Percentages of lesion inhibition were calculated according to Ali et al. (2020).

\section{In-vitro compatibility test of rhizobacteria}

The in-vitro compatibility among different rhizobacterial strains was tested according to Ferreira et al. (2020). A $0.1 \mathrm{ml}$ of one bacterial suspension $\left(10^{8} \mathrm{CFU} \mathrm{ml}{ }^{-1}\right)$ was spread inoculated into Petri plates containing nutrient agar medium. Then four mm size sterilized filter paper (Whatman paper No. 1) discs impregnated with another bacterial suspension were placed on spread inoculated plate as indicated by Mota et al. (2017). Three discs impregnated with a different bacterial suspension were placed at different places at equal distances from each other on a single plate. Spread inoculated Petri plate treated with the disc impregnated with the same bacterial isolate was used as the control. Three replicates were maintained for all treatments. They were incubated at $28 \pm 2{ }^{\circ} \mathrm{C}$ for $96 \mathrm{~h}$. Then, the zone of inhibition was analyzed and recorded as incompatible (-) for the presence of inhibition zone, whereas compatible $(+)$ for the absence of the inhibition zone.

\section{In-vivo biocontrol assay in pot experiments}

Two independent experiments ( 1 and 2$)$ were carried out under greenhouse conditions to test the biocontrol performance of rhizobacterial strains individually and in combination. The selected rhizobacterial strain was inoculated one (experiment 1 ) and three (experiment 2) weeks after faba bean seedling emergence. In this experiment, both susceptible and moderately resistant faba bean varieties were used to evaluate the synergistic effect of rhizobacterial strains and moderately resistant varieties for the management of gall disease. Faba bean seeds susceptible to gall disease (FB-26869) were collected from the Ethiopian Biodiversity Institute (EBI). Whereas the moderately resistant variety (FB-Obse,) was collected from Holota Agricultural Research Institute (HARI). 
Table 1 Treatment details

\begin{tabular}{|c|c|c|}
\hline $\mathrm{S} / \mathrm{N}$ & Treatment codes & Treatments \\
\hline 1 & P1 & Positive control: tested pathogen (AAUO4), no bioagents \\
\hline 2 & $\mathrm{P} 1+\mathrm{B} 1$ & $\mathrm{AA \cup O} 4+P$. aeruginosa AAUS31 \\
\hline 3 & $\mathrm{P} 1+\mathrm{B} 2$ & AAUO4 + P. fluorescens AAUPF62 \\
\hline 4 & $\mathrm{P} 1+\mathrm{B} 3$ & AAUO4+ Bacillus spp. AAUAm28 \\
\hline 5 & $\mathrm{P} 1+\mathrm{B} 4$ & AAUO4+ Bacillus spp. AAUMF42 \\
\hline 6 & $\mathrm{P} 1+\mathrm{B} 1+\mathrm{B} 2$ & AAUO4 + P. aeruginosa AAUS31 + P. fluorescens AAUPF62 \\
\hline 7 & $\mathrm{P} 1+\mathrm{B} 1+\mathrm{B} 3$ & AAUO4 + P. aeruginosa AAUS31 + Bacillus spp. AAUAm28 \\
\hline 8 & $\mathrm{P} 1+\mathrm{B} 1+\mathrm{B} 4$ & AAUO4 + P. aeruginosa AAUS31 + Bacillus spp. AAUMF42 \\
\hline 9 & $\mathrm{P} 1+\mathrm{B} 2+\mathrm{B} 3$ & AAUO4 + P. fluorescens AAUPF62 + Bacillus spp. AAUAm28 \\
\hline 10 & $\mathrm{P} 1+\mathrm{B} 2+\mathrm{B} 4$ & AAUO4 + P. fluorescens AAUPF62 + Bacillus spp. AAUMF42 \\
\hline 11 & $\mathrm{P} 1+\mathrm{B} 3+\mathrm{B} 4$ & AAUO4 + Bacillus spp. AAUAm28 + Bacillus spp. AAUMF42 \\
\hline
\end{tabular}

\section{Preparation of pathogen inoculum}

Three $4 \mathrm{~mm}$ agar plugs of one of our Olpidium isolate 4 (AAUO4) was obtained from the purified culture slant and inoculated in a $250 \mathrm{ml}$ flask containing $100 \mathrm{ml}$ Coon's broth and incubated at $23 \pm 2{ }^{\circ} \mathrm{C}$ for 14 days. The level of conidia suspensions was adjusted to $\left(10^{5}\right.$ spores $\left./ \mathrm{ml}\right)$ by using a hemocytometer. For mass production of the pathogen, $10 \mathrm{ml}$ of the fungal suspension were added to $100 \mathrm{~g}$ sterilized powdered $(0.5 \mathrm{~mm})$ faba bean stems and incubated at $23 \pm 2{ }^{\circ} \mathrm{C}$ for 21 days.

\section{Preparation of rhizobacterial inoculum}

Four in-vitro effective antagonistic rhizobacteria strains (AAUS31, AAUPF62, AAUAm28, and AAUMF42) against the test pathogen (O. viciae) which exhibited plant growth promotion traits were selected to study their in-vivo effects both in mono and dual inoculation treatments on gall disease suppression and growth parameters under greenhouse conditions $\left(15-28{ }^{\circ} \mathrm{C}\right.$ ) in connection with faba bean varieties by pot culture method. For single isolate inoculum production, a loopful of each isolate was separately inoculated in $250 \mathrm{ml}$ flasks containing nutrient broth. After inoculation with bacteria, the flasks were incubated on a rotator shaker at $120 \mathrm{rpm}$ and $28{ }^{\circ} \mathrm{C}$ for $72 \mathrm{~h}$. Before use, bacterial concentration was adjusted to $10^{8}$ cells ml ${ }^{-1}\left(\mathrm{OD}_{620} 0.8-0.9\right)$ using spectrophotometer. Bacterial concentrations were confirmed by dilution plating. The combination of bacterial inoculums was prepared by mixing with an equal volume $(1: 1 \mathrm{v} / \mathrm{v}$ ratio).

\section{Experimental design and treatments details}

The pots were arranged in a complete randomized block design (CRBD) with 3 replications and watered daily. The pots were surface-sterilized for $3 \mathrm{~min}$ with $5 \%$ sodium hypochlorite and washed three times with sterile water and left to dry before use. A mixture of $(1: 1 \mathrm{~m} / \mathrm{m}$ ratio) clay soil and sand were autoclaved at $121{ }^{\circ} \mathrm{C}$ for $1 \mathrm{~h}$. and $2 \mathrm{~kg}$ of them were filled per $20 \mathrm{~cm}$ diameter plastic pots. For treatments of the tested pathogen, four selected individual rhizobacteria strains, and six combined rhizobacteria strains were used with the control treatments. The control group consists of test pathogen without bioagents (Table 1).

\section{Inoculum inoculation}

At the initial stage, surface-sterilized healthy-looking faba bean seeds variety were impregnated with the test pathogen and incubated at $23 \pm 2{ }^{\circ} \mathrm{C}$ for $48 \mathrm{~h}$. before sowing. Seeds impregnated with sterile distilled water were used as control. Four seeds were sown per potted soil. Sowing was made during the first week of May 2019. Secondly, $20 \mathrm{~g}$ of test pathogen colonized faba bean stem powder was used to infest $2 \mathrm{~kg}$ of soil (Ommati and Zaker 2012) five days after the emergence of seedlings at $75 \%$ relative humidity to increase the inoculum source. A $5 \mathrm{ml}$ of bacterial strain $\left(10^{8} \mathrm{CFU} / \mathrm{ml}\right)$ was inoculated per seedling to the base of the stem at $2 \mathrm{~cm}$ depth of soil.

\section{Disease assessment and growth parameters of faba bean}

Disease incidence and severity were evaluated after 25 days of crop emergence. Percent disease incidence was evaluated by counting the number of diseased plants from the total number of inspected plants. The disease percent severity index (PSI) was recorded using a 0-9 scale to determine the area of the infected plant part according to Sheik et al. (2015). Six resistance level were used in this experiment to calculate PSI

$$
\mathrm{PSI}=\frac{a+3 b+5 c+7 d+9 e}{9(a+b+c+d+e)} \times 100
$$

where $9=$ highest rating value, $a=$ number of plants in class $1, b=$ number of plants in class $3, c=$ number of 
Table 2 Phenotypic traits related with biocontrol and plant growth promotion in some strains

\begin{tabular}{|c|c|c|c|c|c|c|c|c|c|}
\hline \multirow[t]{3}{*}{ Isolates code } & \multicolumn{9}{|l|}{ Activities } \\
\hline & \multirow[t]{2}{*}{ Amylase } & \multirow[t]{2}{*}{ Protease } & \multirow[t]{2}{*}{ Cellulase } & \multirow[t]{2}{*}{ Chitinase } & \multirow[t]{2}{*}{ Siderophore } & \multirow[t]{2}{*}{ IAA } & \multirow[t]{2}{*}{$\mathrm{HCN}$} & \multicolumn{2}{|l|}{ Phosphate } \\
\hline & & & & & & & & solubilization & SE (\%) \\
\hline AAUPF62 & + & + & + & + & + & + & +++ & + & $75.00^{\mathrm{a}}$ \\
\hline AAUS31 & - & + & - & + & + & + & +++ & + & $74.07^{\mathrm{a}}$ \\
\hline AAUMF42 & + & + & - & - & - & + & +++ & + & $73.60^{\mathrm{a}}$ \\
\hline AAUAm28 & - & - & + & - & - & + & +++ & + & $69.39^{b}$ \\
\hline AAUW1 & - & + & + & - & - & - & ++ & + & $68.42^{b}$ \\
\hline AAUF2 & + & + & - & - & - & + & - & + & $63.64^{c}$ \\
\hline AAUC2 & - & + & - & - & - & + & + & + & $63.16^{c}$ \\
\hline AAUAm23 & - & + & + & + & + & - & +++ & + & $63.16^{c}$ \\
\hline AAUAm27 & - & + & - & + & - & - & +++ & + & $61.76^{c}$ \\
\hline AAUAm26 & + & + & - & - & - & + & +++ & + & $60.00^{c}$ \\
\hline AAUMF41 & - & - & - & + & + & + & + & + & $58.06^{c}$ \\
\hline AAUF3 & - & + & - & - & + & - & +++ & + & $57.14^{c}$ \\
\hline AAUPS61 & + & - & + & - & + & - & - & + & $52.63^{d}$ \\
\hline AAUMF51 & - & + & + & - & - & - & ++ & + & $52.50^{d}$ \\
\hline AAUW24 & - & + & - & - & + & - & ++ & - & $0.00^{e}$ \\
\hline AAUW2 & - & + & - & + & + & + & ++ & - & $0.00^{e}$ \\
\hline
\end{tabular}

+ presence, - absence, +++ strong, ++ moderate, SE solubilization efficiency, the same letter in the same column indicated the absence of significance difference at $P>0.05$

plants in class $5, d=$ number of plants in class $7, e=$ number of plants in class 9 .

$0=$ Healthy plant, $1=$ only $1-15 \%$ of leaf surface infected, $3=15.1-40 \%$ leaf surface infected with some defoliation, $5=40.1-60 \%$ leaf surface infected with defoliation, $7=60.1-80 \%$ leaf surface infected with defoliation, $9=$ more than $80 \%$ of leaf surface infected with high defoliation.

The seedlings were harvested 70 days after the last inoculation without damaging the root system. A total of four seedlings per treatment were harvested and used to measure the biomass. For each seedling, the biomass index included calculations of the shoot length, shoot fresh weight, pods per plant, shoot dry weight, root length, root fresh weight, and root dry weight at harvest. Once the fresh weight had been measured, the seedlings were oven-dried at $85{ }^{\circ} \mathrm{C}$ for $24 \mathrm{~h}$. to measure the dry weight (Ommati and Zaker 2012).

\section{Statistical analysis}

Collected data were subjected to SPSS statistical software version 20 and one-way ANOVA. The effect of rhizobacterial strains on fungal pathogens was compared using the least significant difference (LSD) at a $5 \%$ probability level $(\mathrm{P} \leq 0.05)$.

\section{Results}

Among 60 potential antagonistic rhizobacteria obtained from rhizosphere of different faba bean were found belong to Pseudomonas (55\%) and Bacillus (25\%) genera. Twenty percent of strains couldn't be identified. All the isolates were studied for hydrolytic enzyme production and plant growth promotion traits. However, due to the vastness of the data, we provide here only multitrait rhizobacteria. The most potential biological control rhizobacteria obtained were related to P. fluorescens (AAUPF62), $P$. aeruginosa (AAUS31), and the genera Bacillus (AAUMF42 and AAUAm28).

\section{Morphological and phenotypic characterization}

The potential antagonistic rhizobacterial isolates exhibited a wide variation in morphological and phenotypic characters. The majority (40\%) of the bacterial isolates were identified as rod-shaped gram-negative and 30\% were identified as rod-shaped gram-positive bacteria. The colony form, elevation, and margin of the majority of bacterial isolates were identified as irregular (28\%), flat $(30 \%)$, and entire (38\%), respectively.

In the $\mathrm{KOH}$ test, most (55\%) isolates revealed sticky lipopolysaccharides. About $63 \%$ of the isolates had utilized citrate and changed Simon's Citrate agar slant from 
green to blue color. All strains were positive for catalase activities. In the Oxidase test, $48 \%$ of the isolates produced an intense deep-purple blue within 5-10 s and exhibited the presence of a cytochrome oxidase.

\section{Assay for hydrolytic enzymes and plant growth promotion traits}

About 25\% of strains were positive for starch hydrolysis, protease $(81 \%)$, cellulase (14\%), and chitinase $(28 \%)$ activities. The majority (63\%) of strains exhibited green to yellow florescent and showed positive for siderophore production. Likewise, 56\% were produced IAA. Most $(60 \%)$ of the isolates were $\mathrm{HCN}$ producers and changed the color of filter paper from yellow to brown with different intensities (Table 2).

Sixty percent of the total isolates solubilize tricalcium phosphate although the solubilization efficiency was varied across the strains. The PF62, S31, and MF42 stains were able to solubilize tricalcium phosphate more than the remaining isolates with solubilization efficiency $75.00,74.07$, and $73.60 \%$, respectively (Table 2 ).

\section{Physico-chemical stress tolerance of the bacterial isolates}

About $45 \%$ of the tested bacterial isolates were unable to grow within $24 \mathrm{~h}$. at low $\mathrm{pH}(\mathrm{pH}=5)$. The strain AAUS31 and AAUPF62 grow fast (within 24 h.) over a wide $\mathrm{pH}$ range (5-6.5) whereas grow slowly (after $72 \mathrm{~h}$.) well at $\mathrm{pH}$ 7 and 7.5. All the tested rhizobacterial strains were able to grow within $24 \mathrm{~h}$. at 25 and $30^{\circ} \mathrm{C}$ whereas grown after $72 \mathrm{~h}$. at 20 and $35^{\circ} \mathrm{C}$. However, $27 \%$ of stains (AAUPF62 and AAUS31) grown fast at $20{ }^{\circ} \mathrm{C}$ whereas $73 \%$ of stains
(AAUAm23, AAUMF42, AAUAm26, AAuAm28, AAUF3, AAU W2, AAUC2, and AAuW24) grown slowly at $20{ }^{\circ} \mathrm{C}$. The bacterial strains exhibited varied tolerance to $\mathrm{NaCl}$. All strains have grown fast at $0.1 \mathrm{M}$. About $45 \%$ of the strains (AAUS31, AAUPF62, AAUMF42, AAUAm26, and AAUW2) grown fast at $0.2 \mathrm{M}$. About $90 \%$ and $45 \%$ of the strains grown slowly at $0.5 \mathrm{M}$, and $0.75 \mathrm{M}$, respectively. However, there were no bacterial strains grown at $1 \mathrm{M}$.

All the tested rhizobacterial strains were resistant to Mancozeb 80\% WP and grown fast within $24 \mathrm{~h}$. at 50 and $100 \mathrm{ppm}$ concentrations. About $36 \%$ of the strains (AAUMF42, AAUPF62, AAUS31, and AAUAm28) were grown fast at $200 \mathrm{ppm}$ whereas $64 \%$ of them grown after $72 \mathrm{~h}$. of incubation at $28 \pm 2{ }^{\circ} \mathrm{C}$. No isolates were found to grow within $24 \mathrm{~h}$. incubation at $300 \mathrm{ppm}$. There were no isolates found to resistant $400 \mathrm{ppm}$ concentration of Mancozeb $80 \%$ WP. Similar patterns were followed by bacterial strains against Copper Oxy Chloride 50\% WP. On the other hand, $100 \%$ of rhizobacterial strains were resistant to the bactericide (Copper Hydroxide 53.8\% WP) at 50 and $100 \mathrm{ppm}$ concentrations. About $18 \%$ of strains (AAUS31 and AAUPF62) were grown fast at $200 \mathrm{ppm}$ while no bacterial strains were found resistant to $400 \mathrm{ppm}$ concentrations of Copper Hydroxide 53.8\% WP.

\section{In-vitro antagonistic assay of rhizobacterial stains on culture media}

The dual culture of bacterial strains against $O$. viciae revealed that a significant reduction in the radial growth over the control. The maximum radial growth inhibition of the pathogen was recorded in the presence of the

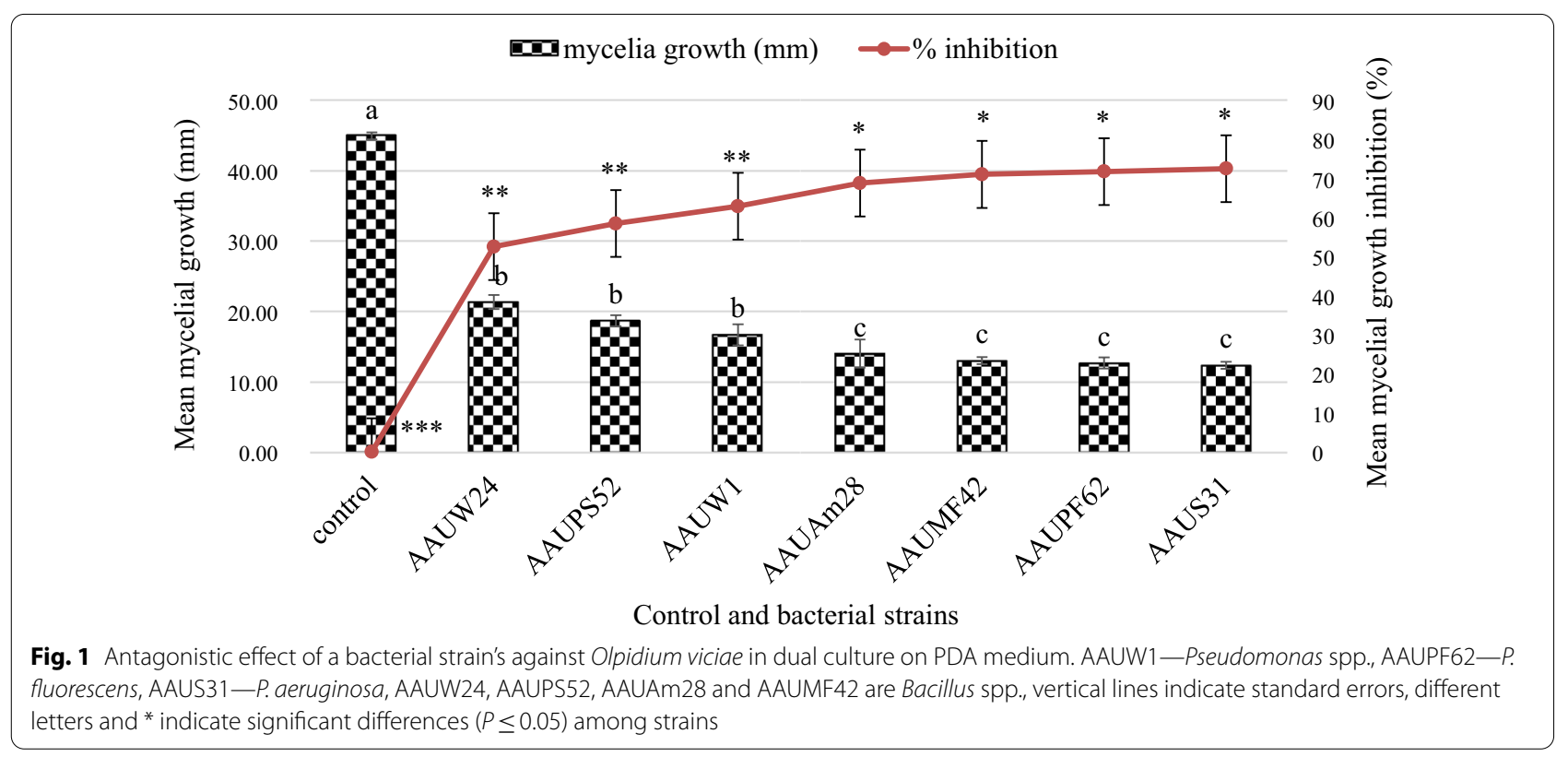




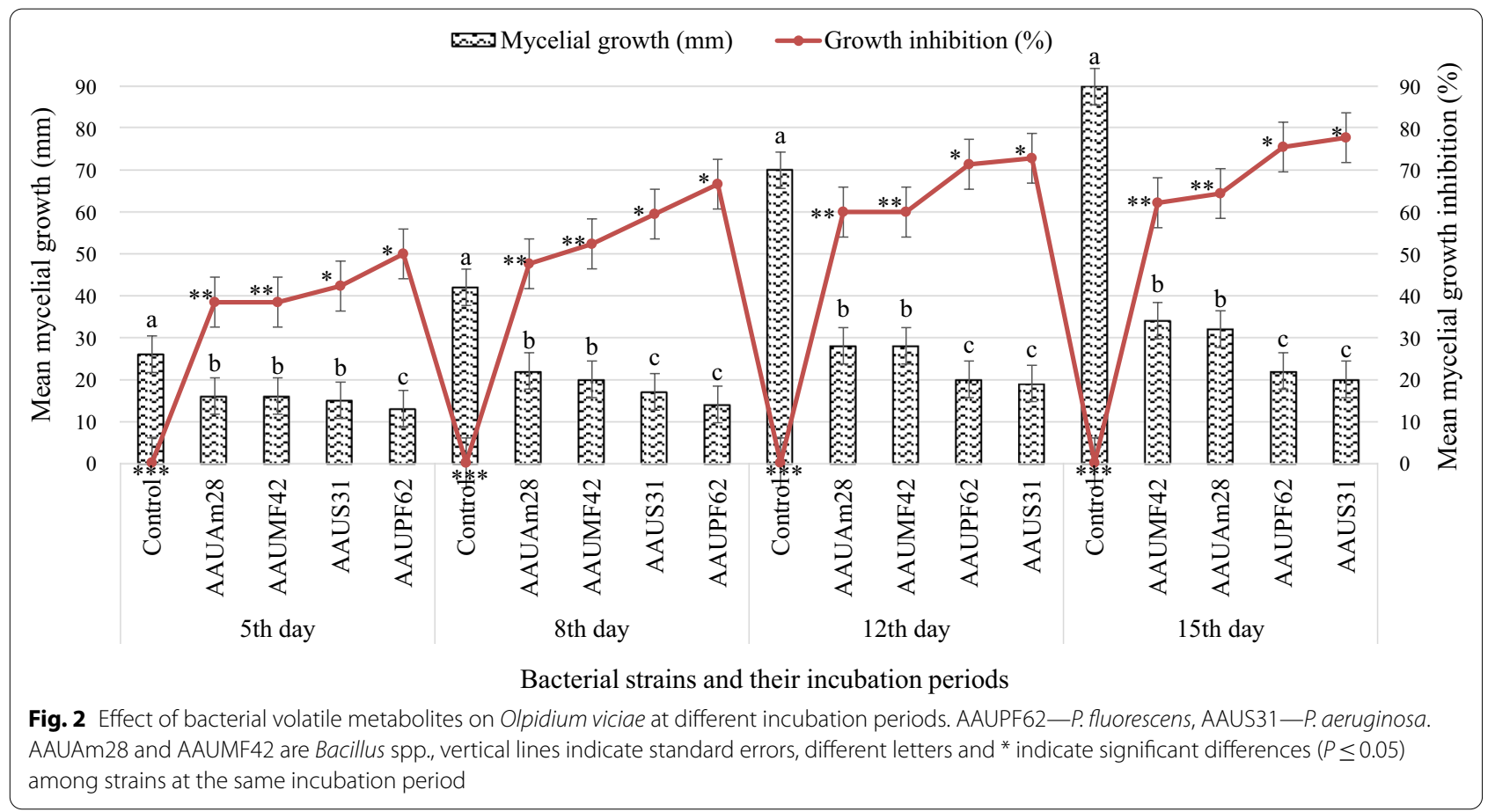

strain AAUS31 (72.59\%), followed by AAUPF62 (71.85\%) and AAUAm28 (68.89\%). However, the fungal mycelial growth inhibition by strains AAUW24 (52.59\%) and AAUPS52 (58.52\%) were lower than others. This showed that the presence of significant variations $(\mathrm{P} \leq 0.05)$ among bacterial strains in reducing the growth of the test pathogen (Fig. 1).

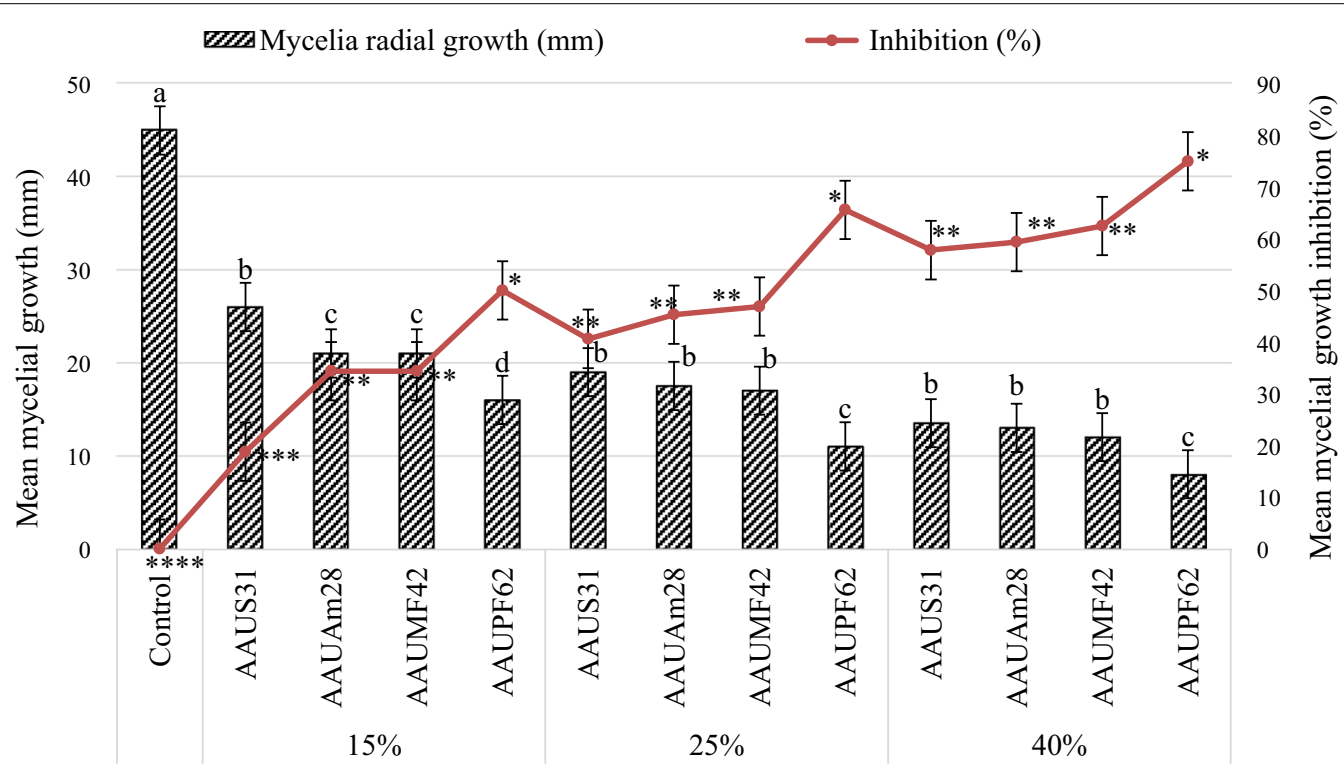

Bacterial strains and their culture filtrate concentrations

Fig. 3 Effect of bacterial culture filtrates on Olpidium viciae at different concentrations. AAUS31—P. aeruginosa, AAUPF62 - P. fluorescens. AAUAm28 and AAUMF42 are Bacillus spp., vertical lines indicate standard errors, different letters and * indicate significant differences $(P \leq 0.05)$ among strains at the same concentration of culture filtrate 
The volatile metabolites produced by the rhizobacterial strains were showed an antagonistic effect against the tested fungal pathogen. As the incubation period increased, the volatile metabolites of bacterial strains significantly reduced the rate of mycelial growth of test pathogens. Percent inhibition of mycelial growth by bacterial strains linearly increased with the incubation period. In the first 8 days of incubation, maximum growth inhibition was recorded by the strain AAUPF62, followed by AAUS31, while after eight days of incubation period reverse results were recorded by the two strains (Fig. 2).

The cell-free culture filtrates (diffusible antifungal metabolites) of the evaluated rhizobacterial strains significantly reduced the mycelial growth of the test pathogen than the control groups. This effect was linearly increased with the concentration of culture filtrates. The diffusible antifungal metabolites of strain AAUPF62 showed a higher antagonistic effect against the test pathogen than other strains throughout the evaluated concentrations, followed by AAUMF42. The 15\% of AAUPF62 culture filtrates exhibited a better antagonistic effect than $25 \%$ of other strains. Similarly, 25\% of AAUPF62 culture filtrates inhibited the mycelial growth of the test pathogen more than the $40 \%$ culture filtrates of other strains (Fig. 3).

\section{In-vitro antagonistic assay of rhizobacterial strains on detached leaves}

The leaflets inoculated with the mycelial disc (Experiment 1) of fungal pathogen and infected faba bean stem disc (Experiment 2) produced progressive lesion from the inoculation point through leaflet. They produced similar leaf lesions symptoms. Significant variation $(\mathrm{P} \leq 0.05)$ was recorded among bacterial isolates in leaf lesions inhibition. Lower degree of leaf lesions recorded on leaves impregnated with bacterial cell suspensions than the control leaflets. The level of length diameter (LD) and width diameter (WD) of leaf lesions was varied based on the bacterial strains used. In experiment 1, The maximum length and width diameter of leaf lesions inhibition was recorded in leaves treated with AAUPF62 $(\mathrm{LD}=58 \%, \mathrm{WD}=46 \%)$, followed by AAUS31 $(\mathrm{LD}=57 \%$, $\mathrm{WD}=46 \%)$, AAUAm $28 \quad(\mathrm{LD}=56 \%, \mathrm{WD}=39 \%)$, and AAUMF42 $(\mathrm{LD}=54 \%$, WD =47\%). Though, AAUPF62, AAUAm28, AAUMF42, and AAUS31 exhibited similar patterns in experiment 2, the level of LD and WD leaf lesions inhibition were different with the values AAUPF62 (LD $=78 \%, W D=73 \%)$, AAUS31 $(\mathrm{LD}=75 \%$, $\mathrm{WD}=73 \%)$, AAUAm $28 \quad(\mathrm{LD}=66 \%, \mathrm{WD}=60 \%)$, and AAUMF42 (LD=58\%, WD =65\%) (Fig. 4).

\section{In-vitro compatibility assay among bacterial strains}

The in-vitro antagonistic assay among potential bacterial strains indicated that there was no zone of inhibition recorded between AAUS31, AAUAm28, AAUMF42, and AAUPF62 strains. Whereas between AAUPF62 and AAU W1 about $18.3 \mathrm{~mm}$ zone of inhibition was recorded (Table 3 ). Hence, those exhibited no zone of inhibition against each other was compatible

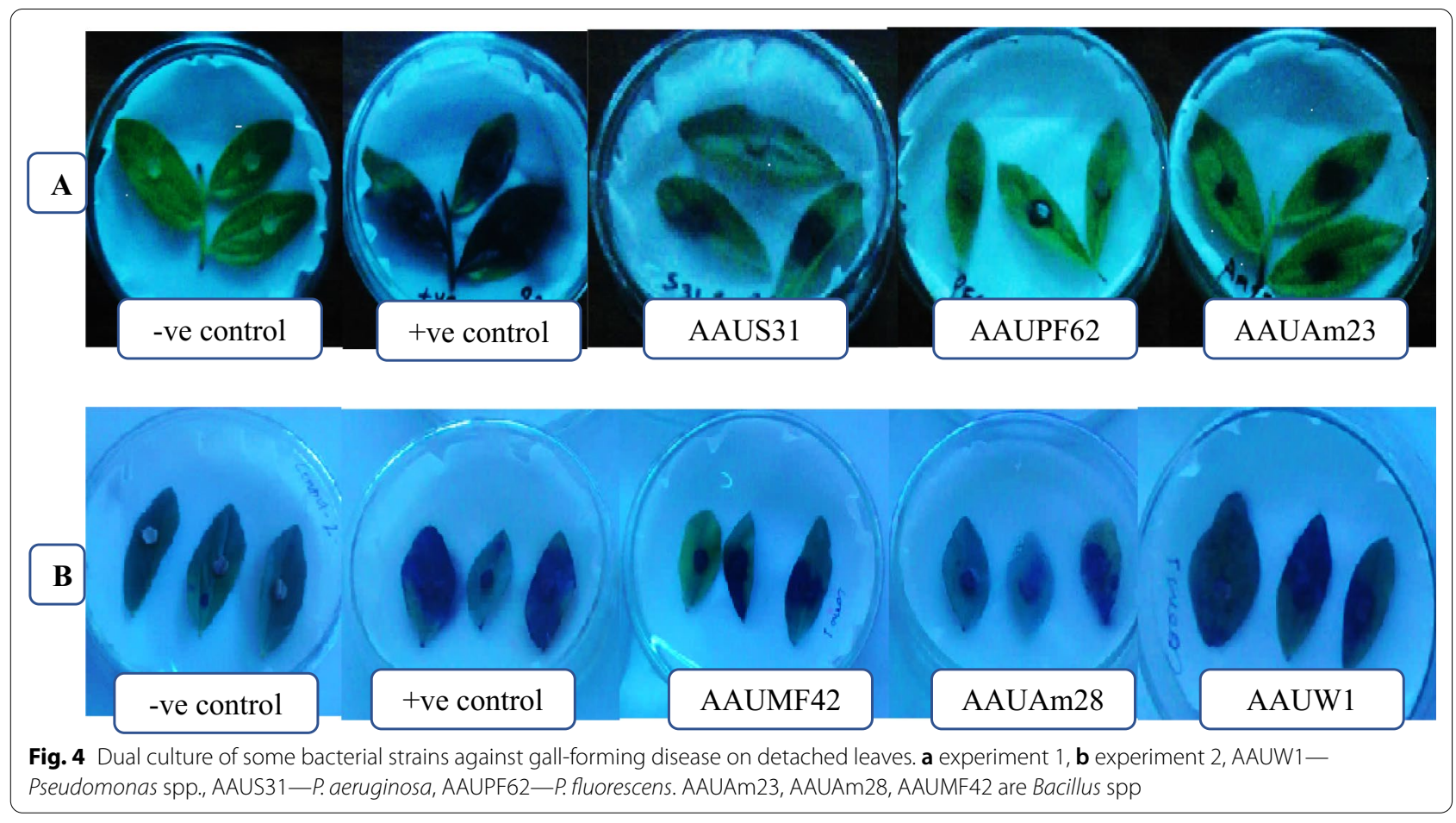


Table 3 In-vitro compatibility assay among bacterial strains

\begin{tabular}{|c|c|c|c|c|c|c|c|c|}
\hline \multirow[t]{2}{*}{ Bacterial isolates code } & \multicolumn{8}{|c|}{ Bacterial isolates with a zone of inhibition in $\mathrm{mm}$} \\
\hline & B1 & B2 & B3 & B4 & B5 & B6 & B7 & B8 \\
\hline AAUS31 (B1) & $+(0.0)$ & & & & & & & \\
\hline AAUAm28 (B2) & $+(0.0)$ & $+(0.0)$ & & & & & & \\
\hline AAUW1 (B3) & $+(0.0)$ & $+(0.0)$ & $+(0.0)$ & & & & & \\
\hline AAUMF42 (B4) & $+(0.0)$ & $+(0.0)$ & $+(0.0)$ & $+(0.0)$ & & & & \\
\hline AAUPF62 (B5) & $+(0.0)$ & $+(0.0)$ & $-(18.3)$ & $+(0.0)$ & $+(0.0)$ & & & \\
\hline AAUF3 (B6) & $+(0.0)$ & $-(11.0)$ & $-(6.7)$ & $-(14.3)$ & $+(0.0)$ & $+(0.0)$ & & \\
\hline AAUW24 (B7) & $+(0.0)$ & $+(0.0)$ & $-(8.3)$ & $-(7.3)$ & $+(0.0)$ & $+(0.0)$ & $+(0.0)$ & \\
\hline AAUF2 (B8) & $+(0.0)$ & $+(0.0)$ & $+(0.0)$ & $+(0.0)$ & $+(0.0)$ & $+(0.0)$ & $+(0.0)$ & $+(0.0)$ \\
\hline
\end{tabular}

+ compatible, - incompatible, values in the bracket are zone of inhibition recorded in $\mathrm{mm}$ between the bacterial isolates

and selected for dual inoculation assay under greenhouse condition.

\section{In-vivo efficacy evaluation of rhizobacteria against gall disease and growth parameters}

In the present investigation, four rhizobacterial strains, from the rhizosphere soil of faba bean plants were assessed for their efficacy in faba bean gall disease reduction and growth parameters enhancement under greenhouse conditions. Non-inoculated faba bean seedlings with rhizobacterial strains showed gall disease symptoms four weeks after crop emergence in the two independent experiments performed ( 1 and 2 ). The first characteristic disease symptoms (galls) were observed
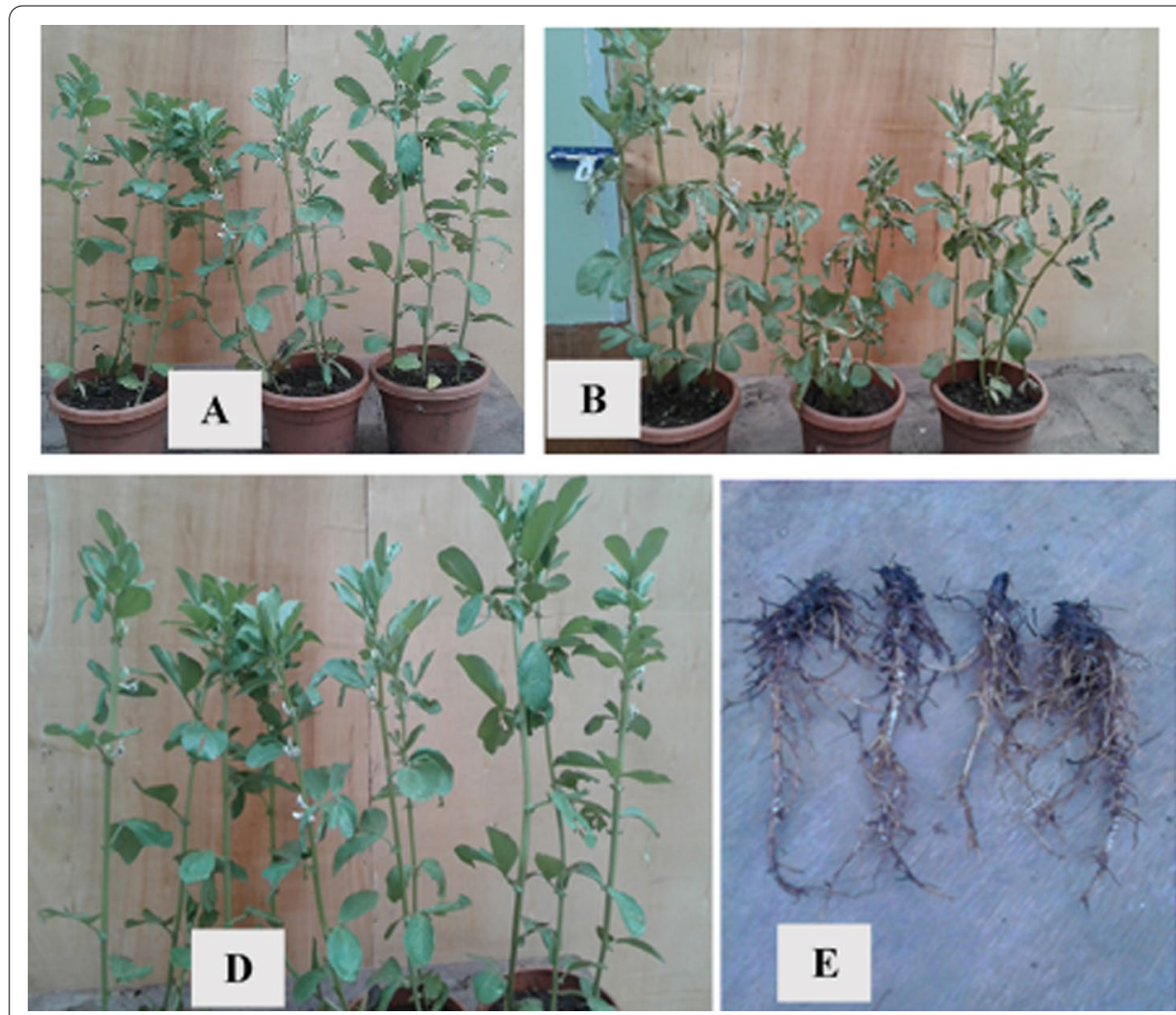

Fig. 5 Rhizobacterial efficacy against gall disease severity, and shoot and root growth promotion in faba bean. a Pathogen non-inoculated control; $\mathbf{b}$ and $\mathbf{e}$, pathogen inoculated control; $\mathbf{c}$ severely infected leaves; $\mathbf{d}$ and $\mathbf{f}$ were treated with co-inoculation of $P$. aeruginosa AAUS31 and $P$. fluorescens AAUF62 strains 
Table $4 P$ values of contrast analysis between treatments

\begin{tabular}{|c|c|c|c|c|c|c|c|c|c|c|c|}
\hline \multirow[t]{2}{*}{ Contrast } & \multirow[t]{2}{*}{ DF } & \multicolumn{3}{|c|}{ Disease data } & \multirow{2}{*}{$\begin{array}{l}\text { DF } \\
\text { Length }\end{array}$} & \multicolumn{3}{|c|}{ Shoot parameter } & \multicolumn{3}{|c|}{ Root parameter } \\
\hline & & AUDPC & Final DI & Final S & & Fresh W & Pods/P & Dry W & Length & Fresh W & Dry W \\
\hline$[\mathrm{P} 1]$ versus $[\mathrm{B} 1 ; \mathrm{B} 2]$ & 43 & $<0.05$ & $<0.05$ & $<0.05$ & $>0.05$ & $>0.05$ & $>0.05$ & $>0.05$ & $>0.05$ & $>0.05$ & $>0.05$ \\
\hline$P 1$ versus $B 3$ & 43 & $0.046^{*}$ & 0.059 & 0.101 & 0.348 & 0.381 & 0.528 & 0.604 & 0.654 & 0.599 & 0.712 \\
\hline$P 1$ versus $B 4$ & 43 & $0.017^{*}$ & $0.029^{*}$ & 0.090 & 0.298 & 0.354 & 0.681 & 0.586 & 0.766 & 0.904 & 0.806 \\
\hline $\mathrm{P} 1$ versus B1B2 & 43 & $<0.001^{*}$ & $<0.001^{*}$ & $<0.001^{*}$ & $0.003^{*}$ & $0.019^{*}$ & $0.007^{*}$ & $0.009^{*}$ & $0.018^{*}$ & $0.045^{*}$ & $0.003^{*}$ \\
\hline $\mathrm{P} 1$ versus $\mathrm{B} 1 \mathrm{~B} 3$ & 43 & $<0.001^{*}$ & $0.002^{*}$ & $0.003^{*}$ & $0.006^{*}$ & 0.102 & $0.042^{*}$ & 0.064 & 0.092 & 0.100 & $0.026^{*}$ \\
\hline$[\mathrm{P} 1]$ versus [B1B4; B2B3] & 43 & $<0.05$ & $<0.05$ & $<0.05$ & $<0.05$ & $>0.05$ & $>0.05$ & $>0.05$ & $>0.05$ & $>0.05$ & $>0.05$ \\
\hline$[\mathrm{P} 1]$ versus [B2B4; B3B4] & 43 & $<0.05$ & $<0.05$ & $<0.05$ & $>0.05$ & $>0.05$ & $>0.05$ & $>0.05$ & $>0.05$ & $>0.05$ & $>0.05$ \\
\hline $\mathrm{B} 1$ versus $\mathrm{B} 1 \mathrm{~B} 2$ & 43 & $0.016^{*}$ & $0.001^{*}$ & 0.094 & $0.022^{*}$ & 0.097 & $0.028^{*}$ & $0.027^{*}$ & 0.092 & 0.185 & $0.009^{*}$ \\
\hline$B 2$ versus $B 1 B 2$ & 43 & 0.053 & $0.032^{*}$ & 0.071 & $0.024^{*}$ & 0.112 & $0.021^{*}$ & $0.020^{*}$ & $0.048^{*}$ & 0.125 & $0.007^{*}$ \\
\hline$B 3$ versus $B 1 B 2$ & 43 & $0.014^{*}$ & $0.000^{*}$ & $0.017^{*}$ & $0.016^{*}$ & 0.401 & $0.023^{*}$ & $0.022^{*}$ & 0.194 & 0.235 & 0.051 \\
\hline$B 4$ versus B1B2 & 43 & $0.038^{*}$ & $0.000^{*}$ & $0.019^{*}$ & $0.019^{*}$ & 0.103 & $0.015^{*}$ & 0.162 & $0.032^{*}$ & 0.122 & $0.004^{*}$ \\
\hline $\mathrm{B} 1 \mathrm{~B} 2$ versus $\mathrm{B} 2 \mathrm{~B} 4$ & 43 & 0.107 & $0.015^{*}$ & 0.314 & 0.060 & 0.161 & $0.034^{*}$ & $0.024^{*}$ & $0.033^{*}$ & 0.097 & $0.006^{*}$ \\
\hline $\mathrm{B} 1 \mathrm{~B} 2$ versus $\mathrm{B} 3 \mathrm{~B} 4$ & 43 & 0.069 & $0.003^{*}$ & 0.230 & $0.050^{*}$ & 0.133 & $0.026^{*}$ & $0.020^{*}$ & $0.030^{*}$ & 0.092 & $0.005^{*}$ \\
\hline FB-Obse versus FB-26869 & 43 & $0.022^{*}$ & $0.014^{*}$ & $<0.001^{*}$ & $0.010^{*}$ & $<0.001^{*}$ & $0.017^{*}$ & $0.006^{*}$ & $0.005^{*}$ & $0.001^{*}$ & $0.028^{*}$ \\
\hline Early versus Late application & 43 & $<0.001^{*}$ & $0.002^{*}$ & $0.010^{*}$ & ND & ND & ND & ND & ND & ND & ND \\
\hline
\end{tabular}

$D F$ - degrees of freedom, ND—no data, $A U D P C$ - area under disease progress curve, DI-disease incidence, $S$-severity, $W$-weight, $P$ - plant, $P 1$ - control (inoculated with Olpidium viciae isolate 4), B1-P. aeruginosa AAUS31, B2-P. fluorescens AAUPF62, B3-Bacillus spp. AAUAm28, B4-Bacillus spp. AAUMF42, FB- faba bean variety

*A significant difference at $5 \%$ probability level

in six (experiment 1) and two (experiment 2) weeks after rhizobacterial inoculation (Fig. 5c). The combined inoculation of $P$. aeruginosa AAUS31 (B1) and P. fluorescens AAUPF62 (B2) delayed the incidence of disease symptoms by one week in both experiments than others. In both experiments, significant $(P<0.001)$ lower disease pressure was recorded in FB-Obse than FB-2689 variety (Table 4). The early application of bioagents more significantly reduced AUDPC $(P<0.001)$, final disease incidence $(P=0.002)$, and final disease severity $(P=0.010)$ than late applications.

A single inoculation of rhizobacterial strains had nonsignificant effect on gall disease severity as compared to the control. Co-inoculation with B1 and B2, and B1and Bacillus spp. AAUAm28 (B3) had shown a significant reduction in final disease severity as compared with the control treatment (Fig. 5d; Table 4). The combined inoculation of B1 and B2 into FB-Obse had exhibited the maximum final disease incidence $(84.08 \%)$ and severity $(92.36 \%)$ reduction in experiment 1 . Whereas in experiment 2 the disease incidence and severity were reduced by 70.02 and $77.09 \%$, respectively.

Rhizobacterial treated FB-Obse variety had shown significantly higher shoot length, shoot fresh weight, pods/plant, shoot dry weight, root length, root fresh weight, and root dry weight over FB-26869 faba bean variety (Table 4). There was no difference in shoot and root growth parameters between the single inoculations (B1, B2, B3, and Bacillus spp. AAUMF42 (B4)) and the control treatment, but combined inoculation of B1 and B2 resulted in significantly $(P<0.05)$ higher shoot and root growth parameters (Table 4). The co-inoculation of B1 and B2 was significantly increased shoot length $(P=0.006$; mean $=108.8 \mathrm{~cm})$ (Fig. $5 \mathrm{~d})$, pods/ plant $(P=0.042$; mean $=6.2$ pods $)$ and root dry weight $(P=0.026$; mean $=10.1 \mathrm{~g})$ (Fig. $5 \mathrm{f})$ over the control treatment. Whereas the dual inoculation of B1B4, B2B3, B2B4, and B3B4 had shown no significant effect on shoot and root growth parameters (Table 4).

The single inoculation with $\mathrm{B} 1$ and $\mathrm{B} 2$ had showed significant effect both on shoot and root growth parameters of the two faba bean varieties (Table 4). The co-inoculation of B1B2 had significantly increased shoot length $(P=0.022 ; \quad$ mean $=122 \mathrm{~cm})$ pods/ plant $(P=0.028$; mean $=6.5$ pods $)$, shoot dry weight $(P=0.027$; mean $=83 . \mathrm{g})$, and root dry weight $(P=0.009$; mean $=14.5 \mathrm{~g}$ ) over single treatments by B1. Similarly, B1B1 had enhanced shoot length $(P=0.024$; mean $=122 \mathrm{~cm})$, pods/plant $(P=0.021 ;$ mean $=6.5$ pods), shoot dry weight $(P=0.020$; mean $=83 \mathrm{~g})$, and root dry weight $(P=0.007$; mean $=14.5)$ over B2 treatment (Table 4).

\section{Discussion}

In this study, indigenous rhizobacterial strains which exhibited antifungal and plant growth promotion activities were isolated from faba bean rhizosphere. The study covers the results of effective potential antagonistic 
strains under both laboratory and greenhouse conditions. Isolates for varieties of biological control and plant growth promotion traits were tested. This offers awareness into the useful variances among isolates and is essential for the careful selection of valuable indigenous strains. The rhizobacterial strains AAUPF62, AAUS31, AAUMF42, and AAUAm28 exhibited more than one biological control and plant growth-promoting trait. This is advantageous to apply them both for disease control and plant growth promotion under adverse conditions. The selected strains were positive for the production of hydrolytic enzyme and able to produce siderophore, IAA, and $\mathrm{HCN}$, and solubilize inorganic phosphate. They were also tolerant to environmental and chemical stresses. Hence, the above-mentioned strains can play the role of antifungal activities and plant growth promotion both directly or indirectly. The dual traits of the strains made them preferable to be selected for further evaluation as a potential biological control agent in this study.

The phenotypic traits and hydrolytic enzymes associated with biological control agents were evaluated as well as their intrinsic tolerance to environmental stress and chemical sensitivities. Faba bean rhizobacteria exhibited tolerance variation in different $\mathrm{pH}$ values, temperature, and $\mathrm{NaCl}$ concentrations. The pattern of these variations among the bacterial isolates could be associated with their genetic makeup. However, Kaur et al. (2018) reported that rhizosphere bacterial strains were relatively sensitive to lower $\mathrm{pH}$ (4). Previous studies also showed the tolerance of some bacterial isolates to $40-45^{\circ} \mathrm{C}$ irrespective of their growth rate (Singh et al. 2013). Also, Mota et al. (2017) reported the $\mathrm{NaCl}$ tolerance variation of various bacterial isolates. We found resistant rhizobacterial isolates to $50-200 \mathrm{ppm}$ concentrations of the tested agrochemicals implying their better survival chance upon exposure to the chemicals and would make it feasible to incorporate these strains in integrated disease management. This is in agreement with Mishra et al. (2013) who reported the compatibility of plant growth-promoting rhizobacteria with fungicides.

Rhizosphere-associated bacteria were positive for protease, siderophore, $\mathrm{HCN}$ production, starch hydrolysis, and phosphate solubilization (Singh et al. 2013). Similarly, Gómez-Lama et al. (2018) reported that siderophore and $\mathrm{HCN}$ producing bacterial isolates from the plant rhizosphere showed remarkable inhibitory effects against the plant fungal pathogens.

Siderophore-producing rhizobacterial strains could stimulate plant growth and inhibit the growth of plant pathogens (Abjala et al. 2015). Siderophore prevents plant pathogens from acquiring enough amount of iron by chelating the ferric ions with high specific activity (Dinesh et al. 2015). Siderophores directly stimulate the biosynthesis of antimicrobial compounds by increasing the availability minerals to the rhizobacteria, which, in turn, suppresses the growth of pathogenic organisms (Abo-Elyousr et al. 2019). The production and release of $\mathrm{HCN}$ by rhizobacterial strains were studied as a biocontrol mechanism (Nandini et al. 2017). HCN is the common secondary metabolite produced by gram-negative Pseudomonas (Abo-Elyousr et al. 2019), which acts as an inducer of plant resistance and is postulated to play a role in the biological control of several plant pathogens (Gómez-Lama et al. 2018). In this study, the strains AAUPF62 and AAUS31 were able to produce protease, chitinase, siderophore, and $\mathrm{HCN}$. These could capable to antagonize and reduced the mycelia growth of the test fungal pathogen.

The strains AAUPF62, AAUS31, AAUMF42, and AAUAm28 exhibited positive IAA producing abilities and phosphate solubilization at various intensities. IAA promotes plant growth and mainly affects the root system by increasing its size and weight (Dinesh et al. 2015). The phosphate solubilizing bacteria would be resulting in increased availability of phosphate ions in the soil and improves plant nutrition (Mota et al. 2017). This could capable to antagonize the test fungal pathogen indirectly and promote healthy plant growth.

The present work found volatile antifungal metabolites produced by strains AAUF62, AAUS31, and AAUMF42 significantly inhibited the mycelia growth of test fungal pathogen with greater than $67 \%$ inhibition. This antagonistic efficacy could be related to their capacity for $\mathrm{HCN}$ production, which is toxic to the test pathogen (Islam et al. 2018). This is in line with the findings of GómezLama et al. (2018) who studied the production and release of $\mathrm{HCN}$ by beneficial rhizosphere bacteria as a biocontrol mechanism. Volatile compounds produced by soil microbes promoted plant growth, showed high antimicrobial activities, and induced systemic resistance in several crops (Abo-Elyousr et al. 2019). In this regard, rhizobacteria are well known for producing large arrays of antifungal and plant growth-promoting metabolites (Raza et al. 2016).

On another hand, the cell-free culture filtrates (diffusible metabolites) of AAUPF62, AAUS31, AAUMF42, and AAUAm28 strains significantly inhibited the mycelial growth of the test pathogen. This inhibitory effect might be associated with the production of hydrolytic enzymes, siderophore, and other diffusible secondary metabolites (Islam et al. 2018). Production of diffusible and volatile antifungal molecules along with hydrolytic enzymes and compounds like siderophore and $\mathrm{HCN}$ seems to be the primary source of growth inhibition of the test pathogen. This is in agreement with the findings of Audrain et al. (2015) and Cernava et al. (2015) who reported the 
antagonistic effect of diffusible and volatile antifungal secondary metabolites of soil microbes against fungal plant pathogens.

In experiments ( 1 and 2 ) of in-vitro detached leaf experiments the average leaf length and width diameter lesion were reduced to more than $50 \%$ by AAUPF62, AAUS31, AAUMF42, and AAUAm28 strains as compared to the positive control. The in-vitro detached leaf experiment was effective to evaluate biocontrol activity of indigenous rhizobacterial strains against fungal pathogen and permitted to find out and select effective strains. The result reported by Ali et al. (2020) the antifungal effect of Rhizospheric bacterial species against phytopathogens on detached leaves and found the result complementing the current work.

The strains AAUPF62, AAUS31, AAUMF42, and AAUAm28 were compatible with each other under invitro conditions. This could be attributed to the existence of synergism between the metabolites produced by the strains. Combining compatible biocontrol agents are a strategic approach to control plant disease. The dual inoculation of compatible biocontrol agents reduced plant disease severity more than mono inoculation of the potential antagonistic rhizobacterial strains (Mota et al. 2017).

In in-vivo biocontrol assay, single inoculation of rhizobacterial strains delayed the gall disease incidence by 3 weeks in experiment 1 and by one week in experiment 2 than in the control treatments. Early incubation of antagonistic rhizobacteria strains (AAUPF62, AAUS31, AAUMF42, and AAUAm28) reduced the disease incidence and severity rates. This could be associated with the induction of systematic resistance in the plants by various secondary metabolites of biocontrol agents (Mohamed et al. 2020). The highest disease severity reduction by AAUPF62 and AAUS31 strains could be related to the siderophore and $\mathrm{HCN}$ production capacity of the strains. On the other hand, the dual inoculation of rhizobacterial strains delayed faba bean gall disease incidence by one week than a single treatment. This exhibited that the existence of synergism among rhizobacterial strains in disease control. In both experiments' lower disease severity was recorded in FB-Obse than in FB-26869 variety. This could be associated with the genetic makeup of the faba bean varieties in addition to the effect of rhizobacterial strains.

Regarding the plant growth-promotion, AAUS31 and AAUPF62 strains increased faba bean shoot and root growth parameters. This implied that the two strains could colonize the root system and play a role in promoting plant growth through IAA production and phosphate solubilization to the useable forms (Abo-Elyousr et al. 2019). There was a large difference between dry weight and fresh weight of faba bean seedlings. The increase in fresh weight could be related to water absorption, while the increase in dry weight could be related to organic matter accumulation. As indicated in the results section, both FB-Obse and FB-26869 faba bean seedlings treated with AAUS31, and AAUPF62 had a long root, which enabled them to obtain sufficient water and nutrients from the soil, the production and regulation of phytohormones lead to increase of biomass (Elkelany et al. 2020). However, the accumulation of organic matter is a slow process and is less in the early stage of plant growth (Aydi-Ben-Abdallah et al. 2020). The dual inoculation of AAUS31 and AAUPF62 significantly increased shoot and root parameters. This could be due to the existence of synergistic effects among bacterial strains.

\section{Conclusions}

Based on in-vitro and greenhouse experiments, 2 rhizobacteria, $P$. fluorescens AAUPF62 and $P$. aeruginosa AAUS31 markedly enhanced faba bean gall disease suppression and increased growth parameter of faba bean than the control group. The 2 strains showed stress tolerance and exhibited multiple biological control and plant growth promotion traits. Hence, they were identified as a potential candidate to be used as a microbial inoculant for the control of faba bean gall disease. The early treatment of the crop by microbial inoculum was advisable. To suppress the effect of gall disease severity by greater than $92 \%$, use of moderately resistant faba bean variety and early co-inoculation of P. fluorescens AAUPF62 and $P$. aeruginosa AAUS31 strains is recommended.

\section{Acknowledgements}

We would like to express our sincere gratitude to Addis Ababa University Thematic Research Directorate for funding this research. We are profoundly grateful to the Ethiopian Biodiversity Institute (EBI) and Holota Agricultural Research Institute (HARI) for the provision of faba bean seed varieties.

\section{Authors' contributions}

$A D, T A$ and $Y W$ : planning of experiments, AD: manuscript preparation and data interpretation, TA and YW: correction of the manuscript with scientific advice. All authors read and approved the final manuscript.

Funding

The authors acknowledge receipt of funding from Addis Ababa University.

\section{Availability of data and materials}

The data set used/or analyzed during the current study are available from the corresponding author on reasonable request.

\section{Declarations}

Ethics approval and consent to participate

Not applicable.

Consent for publication

Not applicable.

Competing interests

The authors declare that they have no competing interest. 


\section{Author details}

'Department of Microbial, Cellular and Molecular Biology, College of Natural and Computational Sciences, Addis Ababa University, 1176 Addis Ababa, Ethiopia. ${ }^{2}$ Department of Zoological Science, College of Natural and Computational Sciences, Addis Ababa University, 1176 Addis Ababa, Ethiopia.

Received: 29 July 2021 Accepted: 14 October 2021

Published online: 01 November 2021

\section{References}

Abjala MA, Odebode AC, Hsu SF, Blackwood CB (2015) Phytobeneficial properties of bacteria isolated from the rhizosphere of maize in southwestern Nigerian soils. Appl Env Microbiol 81:4736-4743. https://doi.org/10.1128/ AEM.00570-15

Abo-Elyousr AM, Bagy KM, Hashem M, Alamri AM, Mostafa SY (2019) Biological control of the tomato wilt caused by Clavibacter michiganensis subsp michiganensis using formulated plant growth-promoting bacteria. Egypt J Biol Pest Cont 29:54. https://doi.org/10.1186/s41938-019-0152-6

Ali A, Ren H, Ahmed T, Luo J, An Q, Qi X, Li B (2020) Antifungal effects of rhizospheric Bacillus species against bayberry twig blight pathogen Pestalotiopsis versicolor. Agronomy 10:1811. https://doi.org/10.3390/agron omy10111811

Alsohim AS, Taylor TB, Barrett GA (2014) The biosurfactant viscosin produced by Pseudomonas fluorescens SBW25 aids spreading motility and plant growth promotion. Env Microbiol 16(7):2267-2281. https://doi.org/10. 1111/1462-2920.12469

Asfaw BM, Dagne K, Wakayo KG, Kemal SA, Muleta KT (2018) Genetic diversity study of Ethiopian Faba bean (Vicia faba L.) varieties based on phenotypic traits and inter simple sequence repeat (ISSR) markers. Afr J Biotechnol 17:433-446. https://doi.org/10.5897/AJB2017.16331

Audrain B, Frag MA, Ryu CM, Ghigo JM (2015) Role of bacterial volatile compounds in bacterial biology. FEMS Microbiol Rev 39:222-233. https://doi. org/10.1093/femsre/fuu013

Aydi-Ben-Abdallah R, Jabnoun-Khiareddine H, Daami-Remadi M (2020) Fusarium wilt biocontrol and tomato growth stimulation, using endophytic bacteria naturally associated with Solanum sodomaeum and $S$. bonariense plants. Egypt J Biol Pest Cont 30:113. https://doi.org/10.1186/ s41938-020-00313-1

Bogale N, Mulugeta T, Setu B, Tesifaye D, Eyeberu A (2017) Management of faba bean gall in faba bean producing area of Eastern Amhara, Ethiopia. J Agric Env Int Dev 111(2):343-350

Cernava T, Aschenbrenner IA, Grube M, Liebminger S, Berg G (2015) A novel assay for the detection of bioactive volatiles evaluated by screening of lichen-associated bacteria. Fron Microbiol 6:398. https://doi.org/10.3389/ fmicb.2015.00398

Dinesh R, Anandaraj M, Kumar A, Bini K (2015) Isolation, Characterization, and evaluation of multi-trait plant growth promoting rhizobacteria for their growth and promoting and disease suppressing effects on ginger. Microbiol Res 173:34-43. https://doi.org/10.1016/j.micres.2015.01.014

Elkelany SU, El-Mougy SN, Abdel-Kader MM (2020) Management of root-knot nematode Meloidogyne incognita of eggplant using some growth-promoting rhizobacteria and chitosan under greenhouse conditions. Egypt $\rfloor$ Biol Pest Cont 30:134. https://doi.org/10.1186/s41938-020-00334-w

Ferreira LD, Carvalho FD, Andrade JF, Oliveira DP, Medeiros FV, Moreira FM (2020) Co-inoculation of selected nodule endophytic rhizobacterial strains with Rhizobium tropici promotes plant growth and controls damping off in common bean. Pedosphere 30(1):98-108. https://doi.org/10. 1016/S1002-0160(19)60825-8

Gómez-Lama C, Legarda G, Pizarro P, Valverd A, Niqui L, Triviño C, Roca A, Mercado-Blanco J (2018) Indigenous Pseudomonas spp. strains from the Olive (Olea europaea L.) rhizosphere as effective biocontrol agents against Verticillium dahliae: From the host roots to the bacterial genomes. Front Microbiol 9:277. https://doi.org/10.3389/fmicb.2018.00277 Haddoud I, Sendi Y, Batnini M, Ben S, Mhadhbi H, Mrabet M (2017) The bean rhizosphere Pseudomonas aeruginosa strain RZ9 strongly reduces Fusarium culmorum growth and infectiveness of plant roots. Span J Agric Res 15(2):e1003. https://doi.org/10.5424/sjar/2017152-10595

Islam A, Nain Z, Alam K, Akhter N, Islam R (2018) In vitro study of biocontrol potential of rhizospheric Pseudomonas aeruginosa against Fusarium oxysporum f. sp. cucumerinum. Egypt J Biol Pest Cont 28:90. https://doi. org/10.1186/s41938-018-0097-1

Kaur A, Devi S, Vyas P (2018) Stress-tolerant antagonistic plant growth-promoting rhizobacteria from Zea mays. J Plant Prot Res 58(2):115-123. https:// doi.org/10.24425/119127

Khaledi N, Taheri P (2016) Biocontrol mechanisms of Trichoderma harzianum against soybean charcoal rot caused by Macrophomina phaseolina. J Plant Prot Res 56(1):21-31. https://doi.org/10.1515/jppr-2016-0004

Mishra G, Kumar N, Giri K, Pandey Sh (2013) In vitro interaction between fungicides and beneficial plant growth promoting Rhizobacteria. Afr J Agric Res 8(45):5630-5633. https://doi.org/10.5897/AJAR11.1526

Mohamed FB, Sallam AN, Alamri MS, Abo-Elyousr MK, Mostafa SY, Hashem M (2020) Approving the biocontrol method of potato wilt caused by Ralstonia solanacearum (Smith) using Enterobacter cloacae PS14 and Trichoderma asperellum T34. Egypt J Biol Pest Cont 30:61. https://doi.org/ 10.1186/s41938-020-00262-9

Mota MS, Gomes CB, Júnior IS, Moura BA (2017) Bacterial selection for biological control of plant disease: criterion determination and validation. Braz J Microbiol 48:62-70. https://doi.org/10.1016/j.bjm.2016.09.003

Nandini M, Selin C, Brawerman G, Fernando D, Kivit T (2017) Hydrogen cyanide which contributes to Pseudomonas chlororaphis strain PA23 biocontrol, is upregulated in the presence of glycine. Biol Contin 108:47-54. https:// doi.org/10.1016/j.biocontrol.2017.02.008

Ommati F, Zaker M (2012) In vitro and greenhouse evaluations of Trichoderma isolates for biological control of potato wilt disease (Fusarium solani). Arch Phytopathol Plant Prot 45(13-16):1715-1723. https://doi.org/10.1080/ 03235408.2012 .702467

Raza W, Ling N, Liu D, Wei Z, Huang Q, Shen Q (2016) Volatile organic compounds produced by Pseudomonas fluorescens WR-1 restrict the growth and virulence traits of Ralstonia solanacearum. Microbiol Res 192:103113. https://doi.org/10.1016/j.micres.2016.05.014

Sheik F, Dehghani H, Aghajani M (2015) Screening faba bean (Vicia faba L.) genotypes for resistance to Stemphylium blight in Iran. Eur J Plant Pathol 143:677-689. https://doi.org/10.1007/s10658-015-0718-4

Singh SK, Jaiswal SK, Vaishampayan A, Dhar B (2013) Physiological behavior and antibiotic response of soybean (Glycine max L.) nodulating rhizobia isolated from Indian soils. Afr J Microbiol Res 7:2093-2102. https://doi. org/10.5897/AJMR12.2263

Suthar KP, Patel RM, Singh D, Parekh VB, Khunt MD, Ahmad T (2017) Isolation and characterization of antagonist bacteria from Chick pea rhizosphere against Fusarium oxysporum f. sp. ciceris. J Pur Appl Microbiol 11(1):371378. https://doi.org/10.22207/JPAM.11.1.48

Teferi TA, Weldemichael GB, Wakeyo GK, Mindaye TT (2018) Fungicidal management of the newly emerging faba bean disease "gall" (Olpidium viciae Kusano) in Tigray, Ethiopia. Crop Prot 107:19-25. https://doi.org/10.1016/j. cropro.2018.01.006

Zhou S, Liu Y, Zhang M, Li B, Chen X (2016) Comparison of the virulence and cognate virulence factors of multinucleate, binucleate and uninucleate Rhizoctonia isolates, causing sheath blight on maize plants. Eur J Plant Pathol 145:501-506. https://doi.org/10.1007/s10658-015-0855-9

\section{Publisher's Note}

Springer Nature remains neutral with regard to jurisdictional claims in published maps and institutional affiliations. 